\title{
Chapter 4 \\ Science and Technology Commitment \\ to the Implementation of the Sendai \\ Framework for Disaster Risk Reduction \\ 2015-2030
}

\section{Virginia Murray}

\begin{abstract}
The Sendai Framework for Disaster Risk Reduction 2015-2030 was adopted by United Nations (UN) member states on 18 March 2015, at the World Conference on Disaster Risk Reduction held in Japan. The Sendai Framework went on to be endorsed by the UN General Assembly in June 2015. The Sendai Framework is wide in scope. This paper uses many resources of already published material to enable the reader to access a more complete summary of the science and technology commitment to the implementation of the Sendai Framework for Disaster Risk Reduction 2015-2030. In this paper on the role of science and technology engagement to provide evidence to inform policy and practice where possible, the author considered it important to emphasis the partnerships and learning she has been a part of and all significant statements that are included in this paper are in italicized quotes. The author is grateful for the many opportunities to engage at many levels with colleagues who also contributed so much to these opportunities for joint working and shared learning.
\end{abstract}

Keywords Sendai Framework - Disaster risk reduction - Scientific and technical • Science-policy $\cdot$ National level $\cdot$ Local level $\cdot$ Humanitarian emergencies

\subsection{Introduction}

The Sendai Framework for Disaster Risk Reduction 2015-2030 was adopted by United Nations (UN) member states on 18 March 2015, at the World Conference on Disaster Risk Reduction held in Japan. The Sendai Framework went on to be

\footnotetext{
V. Murray ( $\square)$

Head of Global Disaster Risk Reduciton, Public Health England, England, UK

e-mail: Virginia.Murray@phe.gov.uk

UNISDR Scientific and Technical Advisroy Group (STAG) member 2008-2017, England, UK

Integrated Research on Disaster Rislk Reduction (IRDR) Scientific Committee, England, UK
}

H. Tatano and A. Collins (eds.), Proceedings of the 3rd Global Summit of Research Institutes for Disaster Risk Reduction, Disaster and Risk Research: GADRI Book Series, https://doi.org/10.1007/978-981-15-8662-0_4 
endorsed by the UN General Assembly in June 2015. ${ }^{1}$ The Sendai Framework is wide in scope. It applies to the 'risk of small-scale and large-scale, frequent and infrequent, sudden and slow-onset disasters, caused by natural or man-made hazards as well as related environmental, technological and biological hazards and risks.' (UNDRR 2015) The Sendai Framework promotes the shifting of the focus from managing disasters to managing risks. This requires a better understanding of risk 'in all its dimensions of vulnerability, exposure' and hazards (UNDRR 2015). The Sendai Framework aims in principle to ensure that the multi-hazard management of disaster risk is factored into the implementation of the Framework at all levels as well as within and across all sectors.

The call has been made to enhance the scientific and technical work on disaster risk reduction in the Sendai Frameworks as follows:

- To enhance the scientific and technical work on disaster risk reduction and its mobilization through the coordination of existing networks and scientific research institutions at all levels and in all regions, with the support of the United Nations Office for Disaster Risk Reduction Scientific and Technical Advisory Group, in order to strengthen the evidence base in support of the implementation of the present Framework; promote scientific research on disaster risk patterns, causes and effects; disseminate risk information with the best use of geospatial information technology; provide guidance on methodologies and standards for risk assessments, disaster risk modelling and the use of data; identify research and technology gaps and set recommendations for research priority areas in disaster risk reduction; promote and support the availability and application of science and technology to decision-making; contribute to the update of the publication entitled '2009 UNISDR Terminology on Disaster Risk Reduction'; use post-disaster reviews as opportunities to enhance learning and public policy; and disseminate studies; (UNDRR 2017-Sendai Framework Paragraph $25 \mathrm{~g}$ ). ${ }^{2}$

Stronger focus on science and building evidence (in its own right and to support scientific advice during preparedness, emergencies and recovery stages) invited engagement of the scientific community in the implementation of the Sendai Framework via the UNISDR Science and Technology Conference on the implementation of the Sendai Framework for Disaster Risk Reduction 2015-2030 held in January 2016, in Geneva Switzerland. ${ }^{3}$ Over 600 organizations and institutions were listed by organization type, region and country as participants at the conference. ${ }^{4}$ A UNISDR

\footnotetext{
${ }^{1}$ United Nations International Strategy for Disaster Reduction (UNISDR), Sendai Framework for Disaster Risk Reduction 2015-2030, available at https://www.unisdr.org/files/43291_sendaiframew orkfordrren.pdf. Accessed 02 August 2017.

${ }^{2}$ See Footnote 1.

${ }^{3}$ UNISDR Science and Technology Conference on the implementation of the Sendai Framework for Disaster Risk Reduction 2015-2030, January 2016. Available at http://www.unisdr.org/partners/ academia-research/conference/2016/. Accessed on 31 July 2017.

${ }^{4}$ UNISDR Science and Technology Conference 27-29 January 2016, List of Organization Participants by organization type, region and country. Available at http://www.preventionweb.net/files/ 45270_listoforganizationsparticipatedinth.pdf. Accessed on 31 July 2017.
} 
Science and Technology Road Map was undertaken to define the aspirations and concrete commitments of the science and technology community over the 20152030 period to support the delivery of the science needed under each of the four Sendai Framework priority areas of action which are:

- Priority 1: Understanding disaster risk.

- Priority 2: Strengthening disaster risk governance to manage disaster risk.

- Priority 3: Investing in disaster risk reduction for resilience.

- Priority 4: Enhancing disaster preparedness for effective response and to 'Build Back Better' in recovery, rehabilitation and reconstruction'. (UNDRR 2015 Sendai Framework Paragraph 20)

It was also identified that there was a need to develop ways to monitor progress and review needs. ${ }^{5}$ Recognizing this, it was agreed that there was a need for peer review publications to report on the conference (Aitsi-Selmi et al. 2016; Dickinson et al. 2016). Following many detailed reflections on the way forward from the UNISDR Science and Technology Conference, Aitsi-Selmi et al. (2016) identified twelve key points with the following two points being of particular relevance to the Global Alliance of Disaster Research Institutes (GADRI) Second Global Summit of Research Institutes for Disaster Risk Reduction ${ }^{6}$ :

- 'Need for formal 'national DRR science-policy councils/platforms' or a form of national focal points for science to support disaster risk reduction and management plans identified. Focal points could include platforms or chief scientific advisors function.

- 'Conducting a periodic review of knowledge needs, new science (including implementation science), and research gaps. More effort is needed to work out how to achieve this and ensure avoiding duplication of effort'. (Aitsi-Selmi et al. 2016)

In summary, there is now an opportunity for the scientific community and its institutions to meet the needs of an increasingly complex environmental and societal landscape to support the breadth of the aspirations to implement the Sendai Framework. This paper therefore reports on a selection of the actions taken by scientists at national, regional and global levels since the UNISDR Science and Technology Conference 2016 conference for the implementation of the Sendai Framework.

\footnotetext{
${ }^{5}$ UNISDR The Science and Technology Roadmap to Support the Implementation of the Sendai Framework for Disaster Risk Reduction 2015-2030. Available at http://www.preventionweb.net/ files/45270_unisdrscienceandtechnologyroadmap.pdf. Accessed on 31 July 2017.

${ }^{6}$ Global Alliance of Disaster Research Institutes (GADRI) Second Global Summit of Research Institutes for Disaster Risk Reduction Available at http://gadri.net/events/2015/12/2015-2nd-global-sum mit-of-research-institutes-for-disaster-risk-reduction-development-of-a-research-.html. Accessed on 31 July 2017.
} 


\subsection{National Level Examples of Science and Technology Activities}

Recognizing the identified call from the UNISDR Science and Technology Conference from the implementation of the Sendai Framework way forward of 'need for formal 'national DRR science-policy councils/platforms' or a form of national focal points for science to support disaster risk reduction and management plans identified' a series of actions at national levels have developed. Examples at such work at national level include:

\subsubsection{Christchurch, New Zealand}

The People in Disasters conference was held in Christchurch on 24-26 February 2016, to coincide with the 5th anniversary of the major Christchurch earthquake of 2011, during which 185 people died and thousands were injured. As reported in the Concluding Statement of the conference 'Christchurch remains a city strongly affected by disaster with ongoing stressors many of them related to the prolonged recovery process'. ${ }^{7}$ Some of the key messages from the conference included the need for an all hazard, multidimensional approach for emergency planning for disaster risk reduction, response, recovery, rehabilitation and reconstruction strengthens the alignment with the global disaster risk reduction community and that mental health impacts were both immediate and latent - a longer term approach to mental health is needed. ${ }^{8}$

A Special Issue of the Australasian Journal of Disaster and Trauma Studies published a series of papers on: caring for companion animals; compassion fatigue among nurses; promoting Māori psychosocial recovery; family violence; managing diabetes post-disaster; comparing community recovery projects in Aotearoa/New Zealand and Japan; wellbeing of older people; and post-traumatic growth (Deely and Ardagh 2017). A report on the Christchurch earthquake mental health impacts and psychosocial recovery demonstrated that it was important to recognize the better understanding of the psychosocial health of the affected public, care providers and early responders, through the diverse voices heard (Hedlund 2016). In addition the Ministry of Health in New Zealand published a Framework for Psychosocial Support in Emergencies reflecting that distress is considerably more prevalent than mental health disorders and, for most people, the distress is tolerable, short-lived and depends on the duration of acute and secondary stressors and that psychosocial recovery is about positively adapting to a changed reality (Ministry of Health 2016). Finally, it

\footnotetext{
${ }^{7}$ Canterbury Clinical Network Transforming Health Care, Whanau Ora ki Waitaha. Concluding statement of the People In Disasters Conference, Christchurch, 2016 Available at http://ccn.health.nz/CCNMembersArea/tabid/1275/ArticleID/912/Concluding-statementof-the-People-in-Disasters-Conference-Christchurch-2016.aspx. Accessed on 31 July 2017.

${ }^{8}$ See Footnote 7.
} 
was determined that 'there was a need for another conference in 5 years to make sure the important work to recovery goes on and is properly documented for the Christchurch and the New Zealand communities but also for shared learning across the world' (Aitsi-Selmi et al. 2016).

\subsubsection{The Philippines}

The 2016 Philippine National Health Research System (PNHRS) Week Celebration conference highlighted their growing commitment to disaster risk reduction (DRR). The event was led by the Philippine Council for Health Research and Development of the Department of Science and Technology (DoST) and the Department of Health and saw the participation of numerous research consortia from all over the Philippines. With a central focus on the Sendai Framework, the conference recognized the significant disaster risks faced in the Philippines while illustrating the strengths and experience in DRR. For example, key innovations in science and technology that were showcased include the web-based hazard mapping applications 'Project NOAH' (Lagmay 2012) and 'FaultFinder' (PHIVOLCS 2016), with another innovation being 'Surveillance in Post Extreme Emergencies and Disasters' (SPEED) (Department of Health 2011) which monitors potential outbreaks through a syndromic reporting system. Three areas noted for further development in DRR science and technology included: integrated national hazard assessment, strengthened collaboration and improved documentation. The combination of the risk profile of the Philippines, established national structures and experience in DRR, as well as scientific and technological innovation in this field are potential factors that could position the Philippines as a future global leader in DRR. The PNHRS conference saw the proposal to develop the Philippines into a global hub for DRR which was published in peer review paper entitled 'Developing the Philippines as a Global Hub for Disaster Risk Reduction-A Health Research Initiative as Presented at the 10th Philippine National Health Research System Week Celebration' (Banwell et al. 2016).

\subsubsection{UK}

\subsubsection{The UK Alliance for Disaster Research (UKADR)}

In 2016, it was agreed that the UK Alliance for Disaster Research ${ }^{9}$ would be developed. The primary motivation for this is to bring together the UK's rich and diverse

\footnotetext{
${ }^{9}$ UK Alliance for Disaster Research Available at http://www.ukadr.org/. Accessed on 1 August 2017.
} 
disaster research community. The aim of the UKADR is that it 'will facilitate collaboration and partnership to aid representation of the research community at government level in the UK, and, where appropriate, help with the implementation of the Sendai Framework for Disaster Risk Reduction'. ${ }^{10}$ The Alliance is independent and managed by voluntary contributions from the UK research community and the current co-chairs are based at the University of Northumbria and King's College, London. The King's College Centre for Integrated Research on Risk and Resilience (CIRRR) ${ }^{11}$ is an Integrated Research on Disaster Research (IRDR) Centre of Excellence ${ }^{12}$ and the UKADR is part of their commitment to IRDR. The 'UKADR membership is open to staff and Ph.D. students of any research-and-capacity-building institute based in the UK that is active in researching disaster risk and its management. This includes universities and other educational institutions, charitable trusts, think tanks and research departments within government agencies, private businesses or civil society organizations' (Banwell et al. 2016). For UKADR, it is agreed that disaster risk reduction, prevention and preparedness, disaster response, reconstruction and recovery are all areas of research interest that are applicable for membership. The first UK Alliance for Disaster Research Annual Conference was held on 9 January 2017 and 10 January 2017 at King's College London, with support from, Durham University and the Cabot Institute, University of Bristol, to help build the UK disaster science community and facilitate networking between all science traditions.

\subsubsection{Natural Environment Research Council Science for Humanitarian Emergencies and Resilience (SHEAR)}

Research funding is critical to support the acquisition of new knowledge. For example, the Natural Environment Research Council (NERC) is one of the UK's leading funders of independent research, training and innovation in environmental science. They invest public money in world-leading science, designed to help sustain and benefit from natural resources, predict and respond to natural hazards and understand environmental change. They work closely with policy-makers and industry to make sure that knowledge can support sustainable economic growth and wellbeing in the UK and around the world. They are supported mainly by the UK Department for Business, Energy and Industrial Strategy (BEIS), but their activities and funding decisions are independent of government. NERC works in partnership with other funders of research, for example, for the Science for Humanitarian Emergencies and Resilience (SHEAR), ${ }^{13}$ a new international research programme jointly funded by

\footnotetext{
${ }^{10}$ See Footnote 9.

${ }^{11}$ King's College London Centre for Integrated Research on Risk and Resilience Available at https:// www.kcl.ac.uk/sspp/research/cirrr/index.aspx. Accessed on 1 August 2017.

${ }^{12}$ Integrated Research on Disaster Research (IRDR) Centre of Excellence Available at http://www. irdrinternational.org/about/structure/icoes/. Accessed on 1 August 2017.

${ }^{13}$ Natural Environment Research Council. Science for Humanitarian Emergencies and Resilience (SHEAR) available at http://www.nerc.ac.uk/research/funded/programmes/shear/. Accessed on 31 July 2017.
} 
the UK's Department for International Development, NERC and the Economic and Social Research Council. The overall SHEAR programme focuses on four areas: disaster risk assessment (mapping and analyses), sub-seasonal to seasonal forecasting, disaster risk monitoring and the integration of these into practical decisionmaking. The programme is targeting lower-to-middle income countries across subSaharan Africa and south Asia, focusing on the co-production of knowledge using a multi-disciplinary and problem-centred approach. The call for proposals closed in January 2016 and the four proposals have been funded until 2020 including two where I am on the advisory boards:

- Forecasts for AnTicipatory HUManitarian action (FATHUM). ${ }^{14}$

- Landslide Multi-Hazard Risk Assessment, Preparedness and Early Warning in South Asia: Integrating Meteorology, Landscape and Society (LANDSLIP). ${ }^{15,16}$

\subsection{Regional-Level Examples of Science and Technology Activities}

Regional-level science and technology has been inspiring in its commitments to developing implementation tools for the Sendai Framework for Disaster Risk Reduction. By using examples from the European Commission, the Pacific Community and from the Belt and Road Initiative led by China, it is possible to show case emerging developments.

\subsubsection{European Commission}

The European Commission has a range of important activities on disaster risk reduction and some of these are summarized below

\footnotetext{
${ }^{14}$ Research Councils UK FATHUM: Forecasts for AnTicipatory HUManitarian action 2016-2020 Lead Research Organisation: University of Oxford Available at http://gtr.rcuk.ac.uk/projects?ref= NE\%2FP00041X\%2F1. Accessed on 1 August 2017.

${ }^{15}$ Research Councils UK Landslide Multi-Hazard Risk Assessment, Preparedness and Early Warning in South Asia: Integrating Meteorology, Landscape and Society 2016-2020 Lead Research Organisation: Available at NERC British Geological Survey Available at http://gtr.rcuk.ac.uk/pro jects?ref=NE\%2FP000649\%2F1. Accessed on 31 July 2017.

${ }^{16}$ Research Councils UK Towards Forecast-based Preparedness Action (ForPAc): Probabilistic forecast information for defensible preparedness decision-making and action 2016-2020. Lead Research Organisation: King's College London Available at http://gtr.rcuk.ac.uk/projects?ref=NE\%2FP000 444\%2F1. Accessed on 31 July 2017.
} 


\subsubsection{Disaster Risk Management Knowledge Centre, Joint Research Centre}

The Disaster Risk Management Knowledge Centre (DRMKC) aims at enhancing the EU and Member States resilience to disasters and their capacity to prevent prepare and respond to emergencies through a strengthened interface between science and policy. ${ }^{17}$ The DRMKC reflects the UN Member state call for the promotion of 'the use and expansion of thematic platforms of cooperation, such as global technology pools and global systems to share know-how, innovation and research and ensure access to technology and information on disaster risk reduction'. (Sendai Framework paragraph $47 \mathrm{c}) .{ }^{18}$

The DRMKC, launched on 30 September 2015, is composed of several Commission services and a network of interested Member States and is part of the European Commission's Science Hub. It will be the focal point of reference to support the work of EU Member States as well as all actors involved in disaster risk management within and beyond the EU. The activities of the DRMKC are to support the translation of complex scientific data and analyses into usable information and provide science-based advice for disaster risk management policies, as well as timely and reliable scientific-based analyses for emergency preparedness and coordinated response activities. It brings together existing initiatives in which science and innovative practices contribute to the management of disaster risks. ${ }^{19}$

In the Executive summary of the Science for Disaster Risk Management 2017: Knowing better and losing less, led by DRMKC, it states that reinforcing the sciencepolicy interface should allow better exploiting and translating the complexities of scientific results into useful and usable policy outputs, through: efficient access and uptake of knowledge and research; a networked approach across relevant stakeholder communities; and continuous efforts towards innovation and new technologies and tools (Poljanšek et al. 2017). The full report addresses the current status of disaster risk management and policy frameworks, the understanding disaster risk: risk assessment methodologies and examples; the need to understand specific disaster risk hazard-related risk issues including geophysical, hydrological, meteorological, climatological and biological risk as well as technological risk; with additional sections on communicating disaster risk, managing disaster risk and future challenges of disaster risk management (Poljanšek et al. 2017).

The report is an important achievement for the UNISDR Science and Technology Conference held on January 2016 call for ' Conducting a periodic review of knowledge needs, new science (including implementation science) and research gaps. More effort is needed to work out how to achieve this and ensure avoiding duplication

\footnotetext{
${ }^{17}$ European Commission Disaster Risk Management Knowledge Centre (DRMKC) Available at https://ec.europa.eu/jrc/en/network-bureau/disaster-risk-management-knowledge-centre. Accessed 2 August 2017.

${ }^{18}$ See Footnote 1.

${ }^{19}$ Disaster Risk Management and Innovation Research Available at http://drmkc.jrc.ec.europa.eu/ overview/About-the-DRMKC. Accessed 2 August 2017.
} 
of effort.' This report is an important next step following on from the impact made in 2013 by the Intergovernmental Panel on Climate Change report on Managing the Risks of Extreme Events and Disasters to Advance Climate Change Adaptation made for encouraging the need for enhanced disaster risk reduction and management issues (IPCC 2012).

\subsubsection{Examples of European Commission Research Programmes of Note for Disaster Risk Reduction}

\section{Community of Users on Secure, Safe and Resilient Societies}

The European Commission has led on many research and capacity building programmes of major significance for the DRR community and developed initiatives to support their dissemination and implementation, e.g. through the Community of Users on secure, safe and resilient societies which is engaged in mapping EU policies and research projects funded by different programmes (under FP7 and H2020) for enhancing partnerships in H2020, and mapping the many programmes dealing with research, capacity building and education/training so a more a greater understanding of the programmes can be shared. ${ }^{20}$ In summary, this group recognizes that in $a$ world where the risks of man-made and natural disasters are ever-growing, the key question is how societies can enhance their resilience and become better prepared' (European Commission Community of Users). The description of this work goes on to state that 'current threats, ranging from natural disasters to crime and terrorism, are posing challenges to the security of citizens, infrastructure and the environment'; and 'In recent years, this topic has hence received increased attention from the European Union (EU)' (European Commission Community of Users). The need to strengthen capacities in disaster risk/crisis management and improving resilience in the fields of CBRN-E (Chemical, Biological, Radiological, Nuclear and Explosive) and natural and man-made disaster management, as well as in the areas of border security and the fight against crime and terrorism, represent key EU policy and research challenges. Regular meetings are held with this Community and are very valuable to attend with much shared learning although the meetings are now live streamed with the outputs are published as summary documents. ${ }^{21}$

Specific examples of research programmes funded by the European Commission include.

\footnotetext{
${ }^{20}$ European Commission A Community of Users on Secure, Safe and Resilient Societies (CoU) Mapping EU policies and FP7 research for enhancing partnerships in H2020date NS. Available at https://www.securityresearch-cou.eu/sites/default/files/adaptivetheme/CoU\%20Brief\%202 01705_05_The\%20CoU\%20Website.pdf. Accessed 2 August 2017.

${ }^{21}$ European Commission A Community of Users on Secure, Safe and Resilient Societies (CoU) Past Events Available at https://www.securityresearch-cou.eu/events. Accessed 2 August 2017.
} 
PLAtform for Climate Adaptation and Risk ReDuction (PLACARD)

PLACARD's mission is to be the recognized platform for dialogue, knowledge exchange and collaboration between the Climate Change Adaptation (CCA) and Disaster Risk Reduction (DRR) communities and I am a member of their Advisory Board. The PLACARD interchange provides, in the large and complex landscape of stakeholder networks, research, policy initiatives and information sources, is working to enhance the coherence of and give direction to CCA and DRR research, policy and practices, strengthening cooperation and countering fragmentation between the domains. Thus, the programme is establishing a comprehensive coordination and knowledge exchange platform for multi-stakeholder dialogue and consultation to address gaps and fragmentation challenges, and support the development and implementation of an evidence base for research and innovation policies. The main work streams are the PLACARD interchange, stocktaking of the decision-making context, knowledge brokerage, institutional strengthening, evaluation, learning and legacy and communications \& online platform. The programme partners are Fundação da Faculdade de Ciências da Universidade de Lisboa, Portugal, The Stockholm Environment Institute, Sweden and UK, Helmholtz-Zentrum Fuer Umweltforschung Gmbh, Germany, Centro Euro-Mediterraneo sui Cambiamenti Climatici Scarl, ITALY, UK Climate Impacts Programme, University of Oxford, United Kingdom, Umweltbundesamt Gmbh, AUSTRIA, University of Geneva, Switzerland, International Red Cross Red Crescent Centre on Climate Change and Disaster Preparedness and Alterra, Wageningen UR, The Netherlands. PLACARD is funded by the European Commission's Horizon 2020 research and innovation programme with the grant agreement No. $653255 .^{22} \mathrm{I}$ am a member of the Advisory Board for PLACARD.

\section{ANYWHERE (EnhANcing EmergencY Management and Response to Extreme WeatHER and Climate Events)}

Extreme weather and climate events are the cause of a number of hazards affecting our society through their impacts on assets, and when interacting with exposed and vulnerable human and natural systems they can lead to disasters. According to the Global Assessment Report on Disaster Risk Reduction ${ }^{23}$ Economic losses from disasters such as earthquakes, flooding, storm surges, wind storms, cyclones and tsunamis are now reaching an average of US\$250 billion to US\$300 billion each year, and two-thirds of them are due to extreme weather hazards such as flood, storm surges and windstorms. ANYWHERE is working to development of tools to support real-time coordination of the emergency response operations to face challenge of the

\footnotetext{
${ }^{22}$ PLAtform for Climate Adaptation and Risk reDuction (PLACARD) 2016-2020. Available at http://www.placard-network.eu/about-us/our-work/. Accessed 2 August 2017.

${ }^{23}$ UNISDR Global Assessment Report on Disaster Risk Reduction 2015 Making development sustainable: The future of disaster risk management Available at http://www.preventionweb.net/ english/hyogo/gar/2015/en/home/index.html. Accessed 2 August 2017.
} 
extreme weather and climate events. It employs cutting edge innovative technologies to develop systems to build a pan-European multi-hazard platform for faster analysis and anticipation of the risk prior the vent occurrence, improved coordination of the emergency actions and assist to raise the self-preparedness. The output is aimed at more effective early warning systems and decision support systems, accompanied by tailored online services developed to support self-preparedness, self-protection and self-response of citizens. The project has a wide range of project partners who are led from the coordination of Universitat Politècnica de Catalunya, Spain. I am a member of the Advisory Board. ANYWHERE is a EC-HORIZON2020-PR700099 programme. $^{24}$

\subsubsection{Pacific Community}

The Pacific Community has shown major leadership in taking forward the science agenda for the implementation of Sendia Framework. For example, the Pacific Platform for Disaster Risk Management 2016 Outcome Statement identified health, science and technology particularly in the following paragraphs ${ }^{25}$ :

'RECOMMEND that Pacific Island countries and territories and partners take relevant steps to improve their understanding of climate and disaster risk, including through ....

3.2 Sound science and technology, including through capacity building and research, with the support of UNISDR Science and Technology Advisory Group (STAG) and explore the development of a Pacific Science and Technology Advisory Group to coordinate science and evidence base sharing for implementation.

\subsection{Documentation and application of traditional and local knowledge systems}

'SUPPORT the professionalization of the resilience sector through capacity building and the establishment of Pacific Regional Federation for Resilience Professionals (PRFRP).

'ACKNOWLEDGE the need for the region to follow International Health Regulations and support the WHO Safe Hospital Programmes' (UNISDR Pacific Platform for Disaster Risk Management 2016 Outcome Statement)

By attending the Platform in Suva, Fiji and related meetings the need for a Pacific Science and Technology Advisory Group was clearly identified in the meetings around the Platform and the fact this was included in the Outcome Statement as a way ahead to regional disaster risk reduction and management health science and technology engagement across the region is invaluable.

\footnotetext{
${ }^{24}$ ANYWHERE (EnhANcing emergencY management and response to extreme WeatHER and climate Events) 2016-2020. Available at http://anywhere-h2020.eu/. Accessed 2 August 2017.

${ }^{25}$ UNISDR Pacific Platform for Disaster Risk Management 2016 Outcome Statement Available at http://www.unisdr.org/files/50790_ppdrm2016outcomestatement.pdf. Accessed 2 August 2017.
} 
Documenting and applying traditional and local knowledge systems is also critical and when I was invited to the University of the South Pacific for a round table with the students, many reported on projects reflecting these topics.

Inclusion in the Outcome Statement of the professionalization of the resilience sector through capacity building and the establishment of Pacific Regional Federation for Resilience Professionals (PRFRP) is an invaluable achievement as well. The Pacific Community and the University of the South Pacific have worked on this topic for some time. By partnering with them and colleagues around the world, a supporting paper on accredited qualifications for capacity development in disaster risk reduction and climate change adaptation was published (Hemstock et al. 2016).

In summary, it was identified that increasingly practitioners and policy-makers working across the globe are recognizing the importance of bringing together disaster risk reduction and climate change adaptation (CCA). It was noted that from studies across 15 Pacific island nations, a key barrier to improving national resilience to disaster risks and climate change impacts has been identified as a lack of capacity and expertise resulting from the absence of sustainable accredited and quality assured formal training programmes in the disaster risk reduction and climate change adaptation sectors. From the work undertaken at the UNISDR Science and Technology Conference in 2016 on the Implementation of the Sendai Framework for Disaster Risk Reduction 2015-2030, it was that much of the training material available are not reviewed either through a peer-to-peer mechanism or by the scientific community and are, thus, not following quality assurance standards. In response to these identified barriers, this paper focused on a call for accredited formal qualifications for capacity development identified in the 2015 United Nations landmark agreements in DRR and CCA and uses the Pacific Islands Region of where this is now being implemented with the launch of the Pacific Regional Federation of Resilience Professionals, for DRR and CCA.

A key issue is providing an accreditation and quality assurance mechanism that is shared across boundaries. By using the United Nations landmark agreements of 2015 , support for a regionally accredited capacity development that ensures all countries can produce, access and effectively use scientific information for disaster risk reduction and climate change adaptation is needed and the newly launched Pacific Regional Federation of Resilience Professionals who work in disaster risk reduction and climate change adaptation may offer a model that can be used more widely. ${ }^{26}$

\footnotetext{
${ }^{26}$ Fiji News. Pacific Regional Federation for Resilience Professionals launched 17:05 Sun Oct 30, 2016 Available at http://trauma.massey.ac.nz/issues/2016-1/AJDTS_20_1_Hemstock.pdf. Accessed 2 August 2017.
} 


\subsubsection{Belt and Road Initiative, China}

China's Belt and Road Initiative (BRI) is a call for an open and inclusive (mutually beneficial) model of cooperative economic, political and cultural exchange (globalization) that draws on the deep-seated meanings of the ancient Silk Roads (Liu and Dunford 2016). The BRI involves the establishment of a framework for open cooperation and new multilateral financial and scientific instruments designed to lay the infrastructural and industrial foundations to secure and solidify China's relations with countries along the Silk Roads.

In November 2016, I attended the First International Science Forum of National Scientific Organizations on the Belt and Road Initiative with 20 national scientific and research organizations from countries and regions along the Belt and Road Initiative. A declaration was made after a two-day forum attended by more than 350 scientists from 40 countries and regions. ${ }^{27}$ The Beijing declaration, establishing an alliance of international scientists to promote cross-border cooperation highlights three areas of consensus

1. 'Strengthen cooperation in science, technology and innovation (STI) for the promotion of shared development',

2. 'Build a platform of co-innovation and a long-term mechanism for STI cooperation',

3. 'Focus on major challenges and organize related international programs' ${ }^{28}$

The Framework for the envisioned Belt and Road Initiative is illustrated in Fig. 4.1 and two examples of programmes that started in 2016 are summarized below.

\subsubsection{Silk Road Disaster Risk Reduction (SiDRR)}

As part of the scientific commitment to disaster risk reduction under the BRI, a 5-year international programme, Silk Road Disaster Risk Reduction (SiDRR), was launched to address issues related to hazards assessment and disaster risk reduction (DRR) was launched at a first workshop in November 2016. The workshop involved contributors from China and other countries including Pakistan, Nepal, Russian, Italy, UK, Sri Lanka and Tajikistan. Risk conditions on Belt and Road Countries (BRCs) were shared and science and technology advancements on DRR have been disseminated during the workshop. The programme agreed to adopt the objectives of Sendai Framework for Disaster Risk Reduction and Sustainable Development Goals and plans to assess disaster risk in BRCs and to propose measures for disaster risk

\footnotetext{
${ }^{27}$ Chinese Academy of Science. Scientists from Belt and Road Countries Gather in Beijing November 2016 Available at http://english.cas.cn/Special_Reports/CAS_in_the_Belt_and_Road_I nitiative/News/201611/t20161118_170714.shtml. Accessed 2 August 2017.

28 'Beijing Declaration' Issued at the First International Science Forum of National Scientific Organizations on the Belt and Road Initiative (Nov. 7-8, 2016) Bulletin of the Chinese Academy of Sciences CAS Vol.30 No.4 2016. Available at http://english.cas.cn/bcas/2016_4/201703/P02017 0310587505348444.pdf. Accessed 3 August 2017.
} 


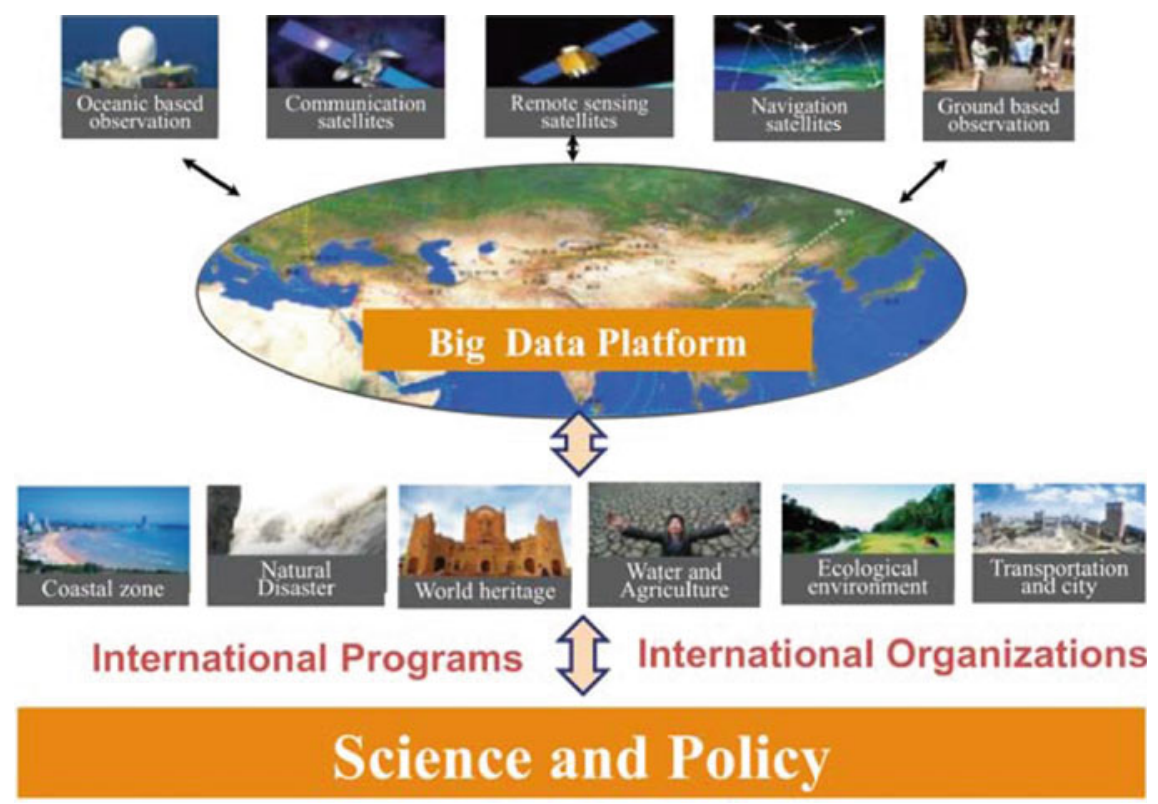

Fig. 4.1 Framework of the envisioned Digital Belt and Road (DBAR) Initiative

reduction which can be appropriate both for specific sites in individual countries and more widely.

\subsubsection{Digital Belt and Road (DBAR)}

Belt and Road region represents the majority of the world's disaster deaths and losses. Given the rapid urbanization and continued population growth trend, the challenges faced by the region are only due to increase in the future. 'Digital Belt and Road' (DBAR) is an initiative that was started in 2016. As with the DRR initiative above the DBAR programme is in agreement with and in support of agreed global frameworks that include the Sendai Framework for Disaster Risk Reduction, the Sustainable Development Goals and the Paris Agreement on climate change. The aim is that under the DBAR framework, DBAR, jointly with Integrated Research on Disaster Risk (IRDR) International Programme Office (IPO), IRDR China National Committee (IRDR CHINA), Institute of Remote Sensing and Digital Earth (RADI), International Society for Digital Earth (ISDE) and CAS-TWAS Centre of Excellence on Space Technology for Disaster Mitigation (SDIM) conduct an international research programme. To do this, a DBAR Disaster Risk Reduction Working Group (DBARDISASTER) was formed to strengthen science capacities for sustainable development and disaster risk reduction, starting from year 2016. The First Consultative Workshop of the DBAR Regional Research Platform for Disaster Risk Reduction 
took place in December 1-2, 2016 in Sanya and a summary of this work is published as the Challenges of Disaster Risk Reduction in the Belt and Road: Contribution of DBAR (Fang et al. 2017).

Much ongoing work continues with the BRI for health, science and technology

\subsection{Global Level Examples of Science and Technology Activities}

Global-level science and technology developments have been inspiring in their commitments to developing implementation approaches for the Sendai Framework for Disaster Risk Reduction. By using examples from the many global organizations, institutions and research programmes such as the International Network for Government Science Advice (INGSA) and associated links including the InterAcademy Partnership (IAP), the International Association for Public Health Institutes (IANPHI), the WMO HIWeather programme, the COST Disaster Bioethics programme and Evidence Aid and their outputs, it is possible to see a few of the exciting developments in science, technology and health for the implementation of the Sendai Framework commitments that are now emerging.

\subsubsection{The International Network for Government Science Advice (INGSA) and Its Links}

The theory, practice and politics of scientific advice that build on the conclusions of an International Council of Science and its partners conference that was held in Auckland in 2014, led to the creation of the International Network for Government Science Advice (INGSA). ${ }^{29}$ It is recognized that scientific advice to governments, as reported by INGSA, has never been in greater demand; nor has it been more contested. From climate change to cybersecurity, poverty to pandemics, food technologies to fracking, the questions being asked of scientists, engineers and other experts by policy-makers, the media and the wider public continue to multiply and increase in complexity. It is of note that at the same time, the authority and legitimacy of experts are under increasing scrutiny, particularly on controversial topics, such as climate change and genetically modified crops. It has been identified that the role of scientific advice and evidence features prominently in recent UN initiatives, such as the Sendai Framework on Disaster Risk Reduction, as identified in a peer review paper entitled 'Ensuring science is useful, usable and used in global disaster risk reduction and sustainable development: a view through the Sendai framework lens' (Aitsi Selmi et al. 2016).

\footnotetext{
${ }^{29}$ International Network for Government Science Advice (INGSA). Available at http://www.ingsa. org/. Accessed 3 August 2017.
} 
Indeed, partnership working for global agendas, through new collaborations like INGSA, the InterAcademy Partnership (Hassan et al. 2015) and the European Science Advice for Policy by European Academies (SAPEA) platform (Reillon 2016) are seen to be increasingly essential. Thus, in the international arena, there are now more regular and intense interactions between science advice, foreign policy and science diplomacy (Gluckman 2016). Several governments, including Japan, New Zealand, USA and the UK, have appointed science advisers to many of their domestic ministries and departments, but now increasingly it is seen as important that they also appoint science advisers to their foreign ministries.

In addition there has been debate about how to strengthen expert advice across the United Nations system, particularly in support of the sustainable development goals (SDGs), agreed by the UN General Assembly in 2015 (ICSU/ISSC 2015). As a result, a new UN Scientific Advisory Board was established in 2014, and a recent review calls for its remit to be expanded by the incoming UN Secretary General (UN SAB 2016).

INGSA's second international summit in Belgium in September 2016 was organized in partnership with the European Commission and addressed Science and Policy-Making: towards a new dialogue. This meeting brought together around 450 experts from seventy countries to debate the state of the art in scientific advice and evidence informed decision-making, across a variety of national and international policy. In the assessment of the Cool heads in crises: How to provide timely advice in emergencies where oil spills, epidemics, earthquakes, nuclear disasters, financial crises and food safety scares were discussed. it was noted that experts may be called upon to explain and respond to emergencies in real time (European Commission 2017). It was agreed that science advice is often viewed as a slow, deliberative process feeding into a complex political system, but, when disaster strikes, the 'rules of the game' change in an instant. It was considered that the timeframe for analysis and advice shortens dramatically and experts are sometimes thrust into the limelight to make public statements or predictions. These pressures can reveal and exacerbate stresses and deficits at the science-policy interface and require the development of robust risk management structures. Suggested solutions included consideration that crisis response: requires stronger science advice systems and to maintain trust when dealing with crises, national authorities should develop, as recommended by OECD in 2015:

- Permanent structures or mechanisms

- A central clearing house and contact point

- Clear reporting processes

- A predefined public communication strategy

- International coordination. ${ }^{30}$

\footnotetext{
${ }^{30}$ Scientific Advice for Policy Making, OECD (2105) Available at http://www.oecd-ilibrary.org/sci ence-and-technology/scientific-advice-for-policy-making_5js331-1jcpwb-en. Accessed 3 August 2017.
} 
Ongoing meetings on evidence informed policy-making continue, including a recent one organized recently by Organisation for Economic Co-operation and Development (OECD) Directorate for Public Governance in cooperation with the European Commission's Joint Research Centre (JRC), the Campbell Collaboration and the International Network for Government Science Advice (INGSA) in June 2017. ${ }^{31}$

\subsubsection{International Association of National Public Health Institutes}

The International Association of National Public Health Institutes (IANPHI) links and strengthens the government agencies responsible for public health, an essential science and organizational resource in many countries for the delivery of the Bangkok Principles for the implementation of the health aspects of the Sendai Framework for Disaster Risk Reduction 2015-2030 that were recommended at the International Conference on the Implementation of the Health Aspect of the Sendai Framework for Disaster Risk Reduction 2015-2030, held on 10-11 March 2016. ${ }^{32}$ In summary, IANPHI improves the world's health by leveraging the experience and expertise of its member institutes to build robust public health systems with 108 members from 93 countries (and growing), benefiting more than 5 billion people on 4 continents (International Association of National Public Health Institutes (IANPHI) 2017).

At the IANPHI's 2016 Annual Meeting in Shanghai, October 17-21 awareness was raised new of global policy and action towards disaster risk reduction and possible engagement opportunities for NPHI following a technical session titled 'Engaging NPHIs and IANPHI in Disaster Risk Reduction'. ${ }^{33}$ The session was moderated by Duncan Selbie, Chief Executive of Public Health England, and it focused on advocacy and implementation of the Sendai Framework for Disaster Risk Reduction 20152030. As discussed, the framework evolved from the need to ensure that disaster risk reduction policy reflects an understanding of the complexity of disaster risk in the twenty-first century and includes health as a key outcome. Implementation calls for a multi-sectoral, transdisciplinary and collaborative all-hazards approach to prevent, prepare for, respond to and recover from disasters. It provides an opportunity to align with twenty-first century global public health strategies through evidencebased policy and action-a key point of synergy with IANPHI and the mission of

\footnotetext{
${ }^{31}$ Organisation for Economic Co-operation and Development (OECD) Governing Better Through Evidence-Informed Policy Making June 2017 Available at http://www.oecd.org/gov/evidence-inf ormed-policy-making.htm. Accessed 3 August 2017.

${ }^{32}$ UNISDR/World Health Organization. Bangkok Principles for the implementation of the health aspects of the Sendai Framework for Disaster Risk Reduction 2015-2030 available at: http://www. who.int/hac/events/2016/Bangkok_Principles.pdf. Accessed 3 August 2017.

${ }^{33}$ International Association of National Public Health Institutes (IANPHI). IANPHI Forms New Disaster Risk Management Group 2016. Available at http://www.ianphi.org/news/2016/disasterrisk management.html. Accessed 3 August 2017.
} 
the member NPHIs (Aitsi-Selmi and Murray 2015; Aitsi-Selmi and Murray 2016). The session resulted in a call to encourage IANPHI and member NPHIs to:

- Advocate on the centrality of health to emergency and disaster risk management

- Incorporate the health aspects of the Sendai Framework within national emergency and disaster risk management policies and measures

- Strengthen collaboration with ministries of health and other stakeholders to address emergency and disaster risk management

- Strengthen the evidence base for health emergency and disaster risk management.

\subsubsection{WMO HIWeather Programme}

With the agreement of the Global Targets and the related indicators the science community is called to respond to the Sendai Framework for Disaster Risk Reduction's target $\mathrm{g}$ ) to 'substantially increase the availability of and access to multi-hazard early warning systems' in the context of weather-related hazards. The World Meteorological Organization has responded to this call with its partners to develop the High Impact Weather (HIWeather) project, a ten-year programme starting in 2016, with its mission to 'Promote cooperative international research to achieve a dramatic increase in resilience to high impact weather, worldwide, through improving forecasts for timescales of minutes to two weeks and enhancing their communication and utility in social, economic and environmental application'. ${ }^{34}$

Recent developments in weather forecasting have transformed our ability to predict weather-related hazards, while mobile communication is radically changing the way that people receive information. At the same time, vulnerability to weatherrelated hazards is growing through urban expansion, population growth and climate change. HIWeather has identified and is promoting research in key multidisciplinary gaps in our knowledge, including in basic meteorology, risk prediction, communication and decision-making that affect our ability to provide effective warnings.

The results showcase leading edge capability aiming to build developing country capacity. In summary, a community that knows the hazards it faces is warned when a hazard approaches, and knows what to do when warned, and is a more resilient community. Thus, HIWeather aims to:

- Improve weather forecasts through advanced observing, data assimilation, modelling and ensembles

- Improve hazard forecasts by closer coupling of weather and hazard models

- Develop impact forecasts, based on each community's vulnerabilities

- Develop improved ways of communicating warning information

- Demonstrate the value of better warnings.

\footnotetext{
${ }^{34}$ World Meteorological Organization. High Impact Weather Project (HIWeather) 2016. Available at https://www.wmo.int/pages/prog/arep/wwrp/new/high_impact_weather_project.html. Accessed 3 August 2017.
} 


\subsubsection{COST Disaster Bioethics Programme-2012-2016}

Disasters raise many ethical dilemmas. Decisions must be made about who receives the limited resources, sometimes with life-and-death consequences. Restrictions may be required to limit the spread of disease or maintain security, but may also interfere with people's rights. Conflict and violence add further complexities, as does taking care of displaced persons and refugees. Yet responders are often provided little or no training to help address such ethical dilemmas, which can lead to moral distress. To address these and other ethical issues, the Disaster Bioethics Action was funded from 2012 to 2016 by the COST IS 1201 Association and supported by the EU Framework Programme Horizon 2020. The network has 28 COST countries participating with over 120 members from academia, non-governmental organizations and international organizations. $^{35}$

In January 2016, at the request of UNISDR and UNESCO, the Action helped to organize an ethics event in Geneva at the implementation conference for the Sendai Framework for Disaster Risk Reduction 2015-2030. The Geneva event identified the need for explicit, ongoing ethics reflection and guidance in many areas of disaster risk reduction. Thus, while the Action has contributed to developing the new field of disaster bioethics, much remains to be done to promote human rights and ethical action during disaster planning, responding and research,

Many publications from the COST Disaster Bioethics programme resulted from the project and of note these include a UNISDR case study (O'Mathúna and Von Schreeb 2015), contributions to the World Health Organization 2016 Guidance for managing ethical issues in infectious disease outbreaks (WHO 2016) and a recent article on research ethics and evidence for humanitarian health (O'Mathúna and Siriwardhana 2017).

\subsubsection{Evidence Aid}

Evidence Aid was established following the tsunami in the Indian Ocean in December 2004. It uses knowledge from systematic reviews to provide reliable, up-to-date evidence on interventions that might be considered in the context of natural disasters and other major healthcare emergencies. Evidence Aid seeks to highlight which interventions work, which does not work, which need more research, and which, no matter how well meaning, might be harmful; and to provide this information to agencies and people planning for, or responding to, disasters. The Mission Statement of Evidence Aid is 'To inspire and enable those guiding the humanitarian sector to apply an evidence-based approach in their activities and decisions' ${ }^{36}$ Evidence Aid links to the Cochrane Library (ISSN 1465-1858) which is a collection of six

\footnotetext{
${ }^{35}$ Disaster Bioethics COST Action IS1201 2012-2016: Disaster Bioethics: addressing ethical issues triggered by disasters. Available at http://disasterbioethics.eu/. Accessed 3 August 2017.

${ }^{36}$ Evidence Aid Available at http://www.evidenceaid.org/who-we-are/. Accessed 4 August.
} 
databases that contain different types of high-quality, independent evidence to inform healthcare decision-making, and a seventh database that provides information about Cochrane groups. ${ }^{37}$

Evidence Aid resources are split into four categories: health issues, emergency type, humanitarian cluster and person groups. In addition to the resources, there are also five disaster-specific collections. Three are available through the Cochrane Library for the topics - burns; post-traumatic stress disorder; and flooding and poor water sanitation). Four special collections are available directly from the evidence aid website-Windstorms, Earthquakes, Ebola, The Health of Refugees and Asylum Seekers in Europe and Zika. ${ }^{38}$

\subsection{National Targets and Indicators of the Sendai Framework}

Adoption of the Sendai Framework by the UN Member States includes agreement on seven global targets to assess global progress in disaster risk reduction. The Sendai Framework states that: 'these targets will be measured at the global level and will be complemented by work to develop appropriate indicators. National targets and indicators will contribute to the achievement of the outcome and goal of the present Framework'. (Sendai Framework Paragraph 18). ${ }^{39}$

The need to support UN member states is also identified in their delivery of UN General Assembly Resolution A/71/644, 'Report of the open-ended intergovernmental expert working group on indicators and terminology relating to disaster risk reduction' (adopted on February 2 2017) (United Nations 2017). This resolution describes the set of indicators to measure global progress in the implementation of the Sendai Framework (Annex 1) and provides the agreed update of the publication entitled '2009 UNISDR Terminology on Disaster Risk Reduction'. Currently technical guidance for countries on indicators, methods and data required for is being prepared for the Global Targets.

The Sendai Framework addresses the need for a shared understanding of disaster risk through its global targets and indicators, which also provide a focus for attention on concerns that are universal to all countries (WHO (World Health Organization) 2015). These targets can act as a catalyst to accelerate change within countries as their high public profile attracts political commitment and financial resources. The benchmarking of targets as a global process can also provide a strong motivating factor for countries. Nevertheless, indicators are not without their limitations. Their measurement often relies on robust and complete data, which may not be available across all countries, resulting in comparability issues. Moreover, indicators have the

\footnotetext{
${ }^{37}$ Cochrane Library Trusted evidence, Informed decisions, Better health. Available at: http://www. cochranelibrary.com/about/about-the-cochrane-library.html. Accessed 4 August 2017.

${ }^{38}$ Evidence Aid Resources, available at http://www.evidenceaid.org/resources/. Accessed 4 August.

${ }^{39}$ See Footnote 1.
} 
potential to be misleading, if the data, assumptions, or analyses behind them are incorrect. Aggregated data, for example, may mask inequalities within vulnerable groups that, unless disaggregated, will remain hidden to policy-makers (Maini et al. 2017).

A UNISDR/Integrated Research on Risk and Resilience/Public Health England workshop on Disaster Loss Data took place in February 2017 at the Royal Society in London, convened following the work completed by the OIEWG on Terminology and Indicators Relating to Disaster Risk Reduction and sought to further develop the loss data technical guidance notes concerning the Global Targets. The discussions at the workshop resulted in a number of proposals for changes and revisions within the technical guidance notes. The UNISDR Secretariat is to review all proposals and will ensure that all changes made to these notes are fully aligned with the discussions of the OIEWG, and in full compliance with General Assembly Resolution A/71/644 (Fakhruddin B, Murray V, Maini R. Disaster loss data in monitoring the implementation of the Sendai Framework ICSU and IRDR. Available at https://www.icsu.org/ cms/ 2017).

Examples of other resources that contribute to supporting the work to deliver the indicators include:

- Integrated Research on Disaster Risk (IRDR $)^{40}$ and its Disaster Loss Data (DATA) project $^{41}$ which are part of a decade-long research programme co-sponsored by the International Council for Science (ICSU), the International Social Science Council (ISSC) and the United Nations Office for Disaster Risk Reduction (UNISDR). It is a global, multi-disciplinary approach to dealing with the challenges brought by natural disasters, mitigating their impacts and improving related policy-making mechanisms. Core funding for IRDR is provided by the China Association for Science and Technology. IRDR International Programme Office is hosted by Institute of Remote Sensing and Digital Earth (RADI) Chinese Academy of Sciences. By working with the International Council for Science: Committee on Data for Science and Technology (CODATA) ${ }^{42}$ and its Linked Open Data for Global Disaster Risk Research ${ }^{43}$ which aims to provide guidance that is of value to national policy for disaster data needs to follow the agreements by the UN Member States after they have determined how they will provide the agreed indicators for the global. A report entitled Gap Analysis on Open Data Interconnectivity for Disaster Risk Research is being completed.

\footnotetext{
${ }^{40}$ Integrated Research on Disaster Risk (IRDR). Available at http://www.irdrinternational.org/. Accessed on 4 August 2015.

${ }^{41}$ Integrated Research on Disaster Risk (IRDR) Disaster Loss Data (DATA) project. Available at http://www.irdrinternational.org/projects/data/. Accessed on 4 August 2015.

${ }^{42}$ International Council for Science: Committee on Data for Science and Technology (CODATA) http://www.codata.org/. Accessed on 4 August 2015.

${ }^{43}$ International Council for Science: Committee on Data for Science and Technology (CODATA) Linked Open Data for Global Disaster Risk Research. Available at http://www.codata.org/task-gro ups/linked-open-data-for-global-disaster-risk-research. Accessed on 4 August 2015.
} 
- The UN Sustainable Development Solutions Network-Data for Sustainable Development - is part of the data revolution which is poised to transform the way governments, citizens and companies do business. ${ }^{44}$ The revolution is being defined by the explosion in availability of data resources and rapidly evolving technologies, which are changing the way data is collected, processed and disseminated. A report entitled 'A World that Counts' 45 provided a link from data for development to data for disasters. The United Nations E/CN.3/2016/2 Economic and Social Council Report of the Inter-agency and Expert Group on Sustainable Development Goal Indicators has now brought together commonalities between the Sendai Framework and the SDG indicators ${ }^{46}$ ongoing work to collaborate continues with many opportunities for continuing joint partnership working and activities to take forward the implementation of the global targets of the Sendai Framework

\subsection{In Summary}

Since the UNISDR Science and Technology Conference on the implementation of the Sendai Framework for Disaster Risk Reduction 2015-2030 held in January 2016, in Geneva Switzerland ${ }^{47}$ extensive and a wide variety of commitment to deliver the Sendai Framework by the science and technology community but it is fragmented. The engagement of the emerging regional Science and Technology Advisory Groups and partners in Africa, Asia, Europe and the Pacific Community will be key to effective partnership building and delivery of the Sendai Framework.

It will be Important to have an effective process for sharing knowledge, building partnerships and clarity on outputs would benefit the S\&T programme for Sendaiimplementation is critical for the Sendai process, requiring a more joined up approach as science and technology evidence for the Sendai indicators will be important for this process.

\footnotetext{
${ }^{44}$ UN Sustainable Development Solutions Network-Data for Sustainable Development. Available at http://unsdsn.org/what-we-do/thematic-networks/data-for-sustainable-development/. Accessed on 4 August 2015.

${ }^{45}$ Independent Expert Advisory Group on a Data Revolution for Sustainable Development A World that Counts Mobilising the Data Revolution for Sustainable Development Report prepared at the request of the United Nations Secretary-General. 2014. Available at http://www.undatarevolution. org/wp-content/uploads/2014/11/A-World-That-Counts.pdf. Accessed on 4 August 2015.

${ }^{46}$ United Nations E/CN.3/2016/2 Economic and Social Council Report of the Inter-agency and Expert Group on Sustainable Development Goal Indicators. Available at https://unstats.un.org/ unsd/statcom/47th-session/documents/2016-2-IAEG-SDGs-E.pdf. Accessed on 4 August 2015.

${ }^{47}$ See Footnote 3.
} 


\section{Annex 1: Global Targets and Indicators of the Sendai Framework Quoted in Full as Adopted by the UN General Assembly in February 2017 (United Nations General Assembly 2017)}

\begin{tabular}{l|l}
\hline & Target A \\
\hline A-1 & Number of deaths and missing persons due to hazardous events per 100,000 populations \\
\hline A-2 & Number of deaths due to hazardous events. \\
\hline A-3 & Number of missing persons due to hazardous events \\
\hline
\end{tabular}

\begin{tabular}{l|l}
\hline & Target B \\
\hline B-1 & Degree of direct affectedness by hazardous events per 100,000 population. \\
\hline B-2 or B-2. alt & $\begin{array}{l}\text { Number of injured or ill people due to hazardous events } \\
\text { Number of people suffering from physical injuries, trauma or cases of disease } \\
\text { requiring medical assistance as a direct result of a hazardous events }\end{array}$ \\
\hline B-3a & Number of evacuated people following hazardous events \\
\hline B-3b & Number of relocated people following hazardous events \\
\hline B-4 & Number of people whose houses were damaged due to hazardous events \\
\hline B-5 & Number of people whose houses were destroyed due to hazardous events \\
\hline B-6 & $\begin{array}{l}\text { Number of people who received aid including food and non-food aid due to } \\
\text { hazardous events }\end{array}$ \\
\hline B-7 & $\begin{array}{l}\text { Number of people whose livelihoods were disrupted, destroyed or lost due to } \\
\text { hazardous events }\end{array}$ \\
\hline
\end{tabular}

\begin{tabular}{l|l}
\hline & Target C \\
\hline C-1 & $\begin{array}{l}\text { Direct economic loss due to hazardous events in relation to global gross domestic } \\
\text { product }\end{array}$ \\
\hline C-2 & Direct agricultural loss due to hazardous events \\
\hline C-3 & $\begin{array}{l}\text { Direct economic loss due to industrial facilities damaged or destroyed by hazardous } \\
\text { events }\end{array}$ \\
\hline C-4 & $\begin{array}{l}\text { Direct economic loss due to commercial facilities damaged or destroyed by hazardous } \\
\text { events }\end{array}$ \\
\hline C-5 & Direct economic loss due to houses damaged by hazardous events \\
\hline C-5b & Damage and loss of administrative buildings \\
\hline C-6 & Direct economic loss due to houses destroyed by hazardous events \\
\hline C-7 & Direct economic loss due to damage to critical infrastructure caused by hazardous events \\
\hline C-8 & Direct economic loss due to cultural heritage damaged or destroyed by hazardous events \\
\hline C-9 & Direct economic loss due to environment degraded by hazardous events \\
\hline C-10 & Total insured direct losses due to hazardous events \\
\hline
\end{tabular}




\begin{tabular}{l|l}
\hline & Target D \\
\hline D-1 & Damage to critical infrastructure due to hazardous events \\
\hline D-2 & Number of health facilities destroyed or damaged by hazardous events \\
\hline D-3 & Number of educational facilities destroyed or damaged by hazardous events \\
\hline D-4 & $\begin{array}{l}\text { Number of transportation units and infrastructures destroyed or damaged by hazardous } \\
\text { events }\end{array}$ \\
\hline D-4b & Kilometres of road destroyed or damaged per hazardous event \\
\hline D-4c & Number of bridges destroyed/damaged by hazardous event \\
\hline D-4d & Kilometres of railway destroyed/damaged by hazardous event \\
\hline D-4 k & Number of airports destroyed/damaged by hazardous event \\
\hline D-4 1 & Number of ports destroyed/damaged by hazardous event \\
\hline D-1 bis & $\begin{array}{l}\text { Number of electricity plants/transmission lines destroyed or damaged by hazardous } \\
\text { events }\end{array}$ \\
\hline D-5 & $\begin{array}{l}\text { Number of times basic services have been disrupted due to hazardous events: education } \\
\text { (D-5a linked to D-2); water (D-5b linked to D-10); health (D-5c linked to D-3); } \\
\text { sewerage (D-5d); transport (D-5e linked to D-4); government services (D-5f); energy } \\
\text { (D-5g); emergency services (D5-h); communications/ICT (D-5i); solid waste (D5-j) }\end{array}$ \\
\hline D-14 & $\begin{array}{l}\text { Number of water and sanitation infrastructures destroyed or damaged by hazardous } \\
\text { events }\end{array}$ \\
\hline
\end{tabular}

\begin{tabular}{c|l}
\hline & Target E \\
\hline E-1 & $\begin{array}{l}\text { Number of countries that adopt and implement national disaster risk reduction strategies in } \\
\text { line with the Sendai Framework for Disaster Risk Reduction 2015-2030 }\end{array}$ \\
\hline E-2 & $\begin{array}{l}\text { Percentage of local governments that adopt and implement local disaster risk reduction } \\
\text { strategies in line with national strategies }\end{array}$ \\
\hline
\end{tabular}

Target $\mathrm{F}$

\section{Category (a) Financial resources}

Headline indicator for Target F-F-6alt

Two formulations

The $10+10$ suggests that a single indicator is selected considering the following 2 options

It is expected that methodology and data will be further developed over time for ODA and ultimately $O O F$

\begin{tabular}{l|l}
\hline Option 1 & \\
\hline F-6 alt & $\begin{array}{l}\text { Total official international support (ODA plus other official flows) for national DRR } \\
\text { actions that is part of government expenditure }\end{array}$ \\
\hline Option 2 & \\
\hline F-6 alt & $\begin{array}{l}\text { Total official international support (ODA plus other official flows) for national DRR } \\
\text { actions that is part of a government-coordinated spending plan }\end{array}$ \\
\hline
\end{tabular}

\section{Supplementary indicators}

\begin{tabular}{l|l}
\hline F-6a & Total amount of national DRR expenditure
\end{tabular} 
(continued)

\begin{tabular}{l|l}
\hline Target F & \\
\hline F-6b & $\begin{array}{l}\text { Total official international support (ODA plus other official flows) for national DRR } \\
\text { actions provided by multilateral institutions }\end{array}$ \\
\hline F-6c & $\begin{array}{l}\text { Total official international support (ODA plus other official flows) for national DRR } \\
\text { actions provided by bilateral entities }\end{array}$ \\
\hline
\end{tabular}

\begin{tabular}{l|l}
\hline & Target G \\
\hline G-1 & Number of countries that have multi-hazard early warning systems \\
\hline G-2 & Number of countries that have a multi-hazard monitoring and forecasting system \\
\hline G-3 & Number of people who have access to early warning information per 100,000 population \\
\hline G-4 & $\begin{array}{l}\text { Percentage of local governments having a contingency or emergency plan to act on early } \\
\text { warnings }\end{array}$ \\
\hline G-6 & $\begin{array}{l}\text { Percentage of local governments that have multi-hazard risk assessment/risk information, } \\
\text { with results in an accessible, understandable and usable format for the people }\end{array}$ \\
\hline G-5 & $\begin{array}{l}\text { Number of countries that have multi-hazard national risk assessment/information, with } \\
\text { results in an accessible, understandable and usable format for the people }\end{array}$ \\
\hline G-7 & $\begin{array}{l}\text { Number of people protected per 100,000 population through pre-emptive evacuation } \\
\text { following early warnings }\end{array}$ \\
\hline
\end{tabular}

\section{References}

Aitsi-Selmi A, Murray V (2015) The Sendai framework: disaster risk reduction through a health lens. Bull World Health Organ 93:362. Accessed 3 Aug 2017

Aitsi-Selmi A, Murray V (2016) Protecting the health and well-being of populations from disasters: health and health care in The Sendai Framework for Disaster Risk Reduction 2015-2030. Prehospital Disaster Med. Accessed 3 Aug 2017

Aitsi-Selmi A, Murray V, Wannous C, Dickinson C, Johnston D, Kawasaki A, Stevance A-S, Yeung $T$ et al (2016a) Reflections on a science and technology agenda for 21 st century disaster risk reduction. Based on the scientific content of the 2016 UNISDR Science and Technology Conference on the Implementation of the Sendai Framework for Disaster Risk Reduction 2015-2030. Int J Disaster Risk Sci 7(1). https://doi.org/10.1007/s13753-016-0081-x. Available at https://link.spr inger.com/article/10.1007/s13753-016-0081-x. Accessed on 1 Aug 2017

Aitsi Selmi A, Blanchard K, Murray V (2016b) Ensuring science is useful, usable and used in global disaster risk reduction and sustainable development: a view through the Sendai framework lens. Palgrave Commun 2, Article number: 16016 (2016). https://doi.org/10.1057/palcomms.2016.16. Available at http://www.nature.com/articles/palcomms201616. Accessed 3 Aug 2017

Banwell N, Montoya J, Opeña M, IJsselmuiden C, Law R, Balboa GJ, Rutherford S, Chu C, Murray V (2016) Developing the Philippines as a global hub for disaster risk reduction-a health research initiative as presented at the 10th Philippine National Health Research System Week Celebration. PLOS Curr Disasters 1. https://doi.org/10.1371/currents.dis.5cf90566bb7791456d cf6b9baf6d4873. Accessed 2 July 2017 
Deely JD, Ardagh MW (2017) First international conference on people in disasters. Aust J Disaster Trauma Stud 20:57-63 Available at http://trauma.massey.ac.nz/issues/2016-2/AJDTS_20-2_Edit orial.pdf. Accessed 31 July 2017

Department of Health (2011) Surveillence in post extreme emergencies and disasters operations manual for managers. Available at http://healthmarketinnovations.org/program/surveilla nce-post-extreme-emergencies-and-disasters-speed. Accessed 2 July 2017

Dickinson C, Aitsi-Selmi A, Basasbe P, Wannous C, Murray V (2016) Global Community of Disaster Risk Reduction Scientists and Decision makers endorse a science and technology partnership to support the implementation of the Sendai Framework for Disaster Risk Reduction 2015-2030. Int J Disaster Risk Sci 7(1). https://doi.org/10.1007/s13753-016-0080-y. Available at https://link. springer.com/article/10.1007/s13753-016-0080-y. Accessed on 1 Aug 2017

European Commission (2017) Science \& policy making — towards a new dialogue. Report on the 2nd International Network for Government Science Advice Conference Science and Policy Making: towards a new dialogue, Brussels, 29-30 September 2016. ISBN 978-92-79-63020-0. https://doi. org/10.2782/977668 HC-06-16-175-EN-N @ European Union, 2017 Available at http://www. ingsa.org/wp-content/uploads/2017/03/2nd_ingsa_final_report.pdf. Accessed on 3 Aug 2017

Fakhruddin B, Murray V, Maini R. Disaster loss data in monitoring the implementation of the Sendai Framework ICSU and IRDR. Available at https://www.icsu.org/cms/2017/05/DRR-policy-brief2-data.pdf (Accessed on 4 August 2015)

Fang C, Shaw R, Abedin MA, Briceno S, Dixit AM, Gupta M, Hugo W, Gensuo J, Murray V, Myint A, Pereira JJ, Rahman A, Sharma VK, Triutomo S, Wang X, Wickramsinghe D (2017) Challenges of disaster risk reduction in the belt and road: contribution of DBAR 52 challenges of disaster risk reduction in the belt and road. Bull Chin Acad Sci 32. Available at http://www. bulletin.cas.cn/publish_article/2017/Z1/2017Z120.htm. Accessed 3 Aug 2017

Gluckman P (2016) The science-policy interface. Science 353(6303):969. Available at http://sci ence.sciencemag.org/content/353/6303/969/tab-pdf. Accessed 3 Aug 2017

Hassan M, ter Meulen V, McGrath P, Fears R (2015) Academies of science as key instruments of science diplomacy. Science and Diplomacy. March 2015. AAAS, Washington DC. Available at http://www.sciencediplomacy.org/files/acadmies_of_science_as_key_instruments_of_sci ence_diplomacy_science_diplomacy_1.pdf. Accessed 3 Aug 2017

Hedlund K (2016) People in disasters conference 2016: learning report-Christchurch earthquake: mental health impacts and psychosocial recovery 2016. ISBN: 978-0-473-39342-7. Available at http://trauma.massey.ac.nz/conference/PID_Learning_Report_2017.pdf. Accessed 31 July 2017

Hemstock S, Buliruarua L-A, Chan E, Chan G, Jacot Des Combes H, Davey P, Farrell P, Griffiths S, Hansen H, Hatch T, Holloway A, Manuella-Morris T, Martin T, Renaud FG, Ronan K, Ryan B, Szarzynski J, Shaw1 D, Yasukawa S, Yeung T, Murray V (2016) Accredited qualifications for capacity development in disasterrisk reduction and climate change adaptation. Austral J Disaster Trauma Stud 20:16-33 Available at http://trauma.massey.ac.nz/issues/2016-1/AJDTS_20_1_H emstock.pdf. Accessed 2 Aug 2017

ICSU/ISSC (2015) Review of targets for the sustainable development goals: the science perspective. ICSU/ISSC, Paris. Available at https://www.icsu.org/publications/reports-and-reviews/reviewof-targets-for-the-sustainable-development-goals-the-science-perspective-2015. Accessed 3 Aug 2017

International Association of National Public Health Institutes (IANPHI) (2017) Available at http:// www.ianphi.org/whoweare/index.html. Accessed 3 August 2017

IPCC (2012) Managing the risks of extreme events and disasters to advance climate change adaptation. In: Field CB, Barros V, Stocker TF, Qin D, Dokken DJ, Ebi KL, Mastrandrea MD, Mach KJ, Plattner GK, Allen SK, Tignor M, Midgley PM (eds) A special report of Working Groups I and II of the Intergovernmental Panel on Climate Change. Cambridge University Press, Cambridge, 582pp. Accessed 2 Aug 2017

Lagmay A (2012) Disseminating near-real time hazards information and flood maps in the Philippines through web-GIS. Project NOAH Open File Reports, 1, 21-36. Available at http://blog. noah.dost.gov.ph/category/open-file-reports/. Accessed 2 July 2017 
Liu W, Dunford M (2016) Inclusive globalization: unpacking China's belt and road initiative area development and policy. 1(3). Available at http://rsa.tandfonline.com/action/showCitFormats? doi $=10.1080 \% 2 F 23792949.2016 .1232598$. Accessed 2 Aug 2017

Maini R, Clarke L, Blanchard K, Murray V (2017) The Sendai Framework for Disaster Risk Reduction and its indicators-where does health fit in? Int J Disaster Risk Sci. https://doi.org/ 10.1007/s13753-017-0120-2. Available at https://link.springer.com/article/10.1007/s13753-0170120-2?wt_mc=Internal.Event.1.SEM.ArticleAuthorOnlineFirst. Accessed on 4 Aug 2015

Ministry of Health (2016) Framework for psychosocial support in emergencies. Ministry of Health, Wellington. Available at https://www.health.govt.nz/system/files/documents/publicati ons/framework-psychosocial-support-emergencies-dec16-v2.pdf. Accessed 31 July 2017

O'Mathúna DP, Von Schreeb J (2015) Ethical dilemmas with amputations after earthquakes. In: UNISDR Scientific and Technical Advisory Group Case Studies. Available at http://bit.ly/1z9 $\mathrm{NVgl}$

O'Mathúna D, Siriwardhana C (2017) Research ethics and evidence for humanitarian health. Lancet. Available at http://www.sciencedirect.com/science/article/pii/S014067361731276X. Accessed 3 Aug 2017

PHIVOLCS (2016) FaultFinder. Retrieved from http://faultfinder.phivolcs.dost.gov.ph/. Accessed 2 July 2017

Poljanšek K, Marín Ferrer M, De Groeve T, Clark I, Faivre N, Peter D, Quevauviller PK, Boersma KE, Krausmann E, Murray V, Papadopoulos GA, Salamon P, Simmons DC, Wilkinson E, Casajus Valles A, Doherty B, Galliano D (2017a) Science for disaster risk management 2017: knowing better and losing less. Executive Summary. EUR 28034 EN, Publications Office of the European Union, Luxembourg, ISBN 978-92-79-69673-2, https://doi.org/10.2760/451402, JRC102482. Available at http://drmkc.jrc.ec.europa.eu/portals/0/Knowledge/ScienceforDRM/ Executive_Summary_of_Science_for_DRM_2017.pdf. Accessed 2 Aug 2017

Poljanšek K, Marin Ferrer M, De Groeve T, Clark I (eds) (2017b) Science for disaster risk management 2017: knowing better and losing less. EUR 28034 EN, Publications Office of the European Union, Luxembourg, 2017, ISBN 978-92-79-60679-3, https://doi.org/10.2788/ 842809, JRC102482. Available at https://ec.europa.eu/jrc/en/publication/science-disaster-riskmanagement-2017-knowing-better-and-losing-less. Accessed 2 Aug 2017

Reillon V (2016) Scientific advice for policy-makers in the European Union. European Parliamentary Research Service Briefing. September 2016. European Parliamentary Research Service Members' Research Service PE 589.777. Available at http://www.europarl.europa.eu/RegData/ etudes/BRIE/2016/589777/EPRS_BRI(2016)589777_EN.pd. Accessed 3 Aug 2017

United Nations (2017) Report of the open-ended intergovernmental expert working group on indicators and terminology relating to disaster risk reduction. United Nations A/71/644 http://www. preventionweb.net/files/50683_oiewgreportenglish.pdf. Accessed 4 Aug 2017

United Nations General Assembly (2017) Report of the open-ended intergovernmental expert working group on indicators and terminology relating to disaster risk reduction United Nations Seventy-first Session A/71/644. Distr.: General 1 December 2016, adopted February 2017. Available at https://www.preventionweb.net/files/50683_oiewgreportenglish.pdf (Accessed on 1 February 2020)

WHO (World Health Organization) (2015) Global reference list of 100 core health indicators. Available at http://apps.who.int/iris/bitstream/10665/173589/1/WHO_HIS_HSI_2015. 3_eng.pdf. Accessed 4 Aug 2017

WHO (2016) Guidance for managing ethical issues in infectious disease outbreaks. ISBN 97892 41549837 (C) World Health Organization 2016 Available at http://apps.who.int/iris/bitstream/ 10665/250580/1/9789241549837-eng.pdf. Accessed 3 Aug 2017 
Open Access This chapter is licensed under the terms of the Creative Commons Attribution 4.0 International License (http://creativecommons.org/licenses/by/4.0/), which permits use, sharing, adaptation, distribution and reproduction in any medium or format, as long as you give appropriate credit to the original author(s) and the source, provide a link to the Creative Commons license and indicate if changes were made.

The images or other third party material in this chapter are included in the chapter's Creative Commons license, unless indicated otherwise in a credit line to the material. If material is not included in the chapter's Creative Commons license and your intended use is not permitted by statutory regulation or exceeds the permitted use, you will need to obtain permission directly from the copyright holder.

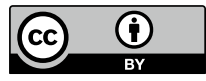

